\title{
HUBUNGAN ANTARA PENGETAHUAN DENGAN PERILAKU PENCEGAHAN PENULARAN TB PADA PENDERITA TB PARU DI POLI PARU RUMAH SAKIT PROF. DR.SULIANTI SAROSO
}

\author{
RELATIONSHIP BETWEEN BEHAVIOR OF KNOWLEDGE IN TB \\ INFECTION PREVENTION OF PULMONARY TB PATIENTS IN \\ CLINIC LUNG, HOSPITAL PROF.DR. SULIANTI SAROSO.
}

\author{
Dian Noviati Kurniasih, Cicilia Widianingsih \\ Rumah Sakit Penyakit Infeksi Prof. Dr. Sulianti Saroso
}

\begin{abstract}
Abstrak : TB merupakan penyakit menular yang menjadi masalah di Indonesia karena diperkirakan setiap hari 425 orang meninggal akibat TB di Indonesia. Perilaku pencegahan TB dilakukan untuk menurunkan angka penularan penyakit TB terhadap orang - orang di lingkungan sekitar. Pengetahuan tentang pencegahan penularan TB paru merupakan bekal utama untuk mencegah penularan dan penyebaran penyakit Tuberkulosis Paru. Perilaku dapat terdiri dari pengetahuan, sikap dan tindakan. Penelitian ini merupakan penelitian kuantitatif dengan jenis deskriptif korelatif dengan desain cross sectional. Sampel sebanyak 60 pasien yang diambil dengan teknik rondom sampling. Penelitian ini bertujuan mengetahui hubungan pengetahuan dengan perilaku pencegahan penularan TB Paru. Hasil penelitian menyebutkan bahwa 96,7\% responden berpengetahuan rendah, $100 \%$ bersikap mendukung dalam pencegahan TB Paru dan 100\% berperilaku tidak mendukung pencegahan TB paru. Hasil analisa bivariat menggunakan regresi linier menunjukkan bahwa terdapat hubungan pengetahuan dengan pencegahan TB paru.
\end{abstract}

\begin{abstract}
TB is an infectious disease due to a problem in Indonesia is estimated every day 425 people died from TB in Indonesia. TB preventive behavior is done to reduce the rate of transmission of TB to people - people in the neighborhood. Knowledge of prevention of transmission of TB is the main provision to prevent the transmission and spread of pulmonary tuberculosis. The behavior may consist of knowledge, attitudes and actions. This research is a quantitative study with a descriptive correlative with the cross-sectional design. Sample has collected amount 60 patients were taken by random sampling. This objective study to determine the relationship of knowledge with pulmonary TB infection prevention behavior. The result study $96.7 \%$ of respondent knowledgeable low, $100 \%$ attitude supportive in the prevention of pulmonary TB and $100 \%$ behavior not support the prevention of pulmonary tuberculosis. The linear regression indicates that there is a relationship of knowledge to the prevention of pulmonary tuberculosis.
\end{abstract}

Korespondensi : Dian Noviati Kurniasih, RSPI Prof. Dr. Sulianti Saroso, Jl. Baru Sunter Permai, Papanggo, Tanjung Priok, Jakarta Utara, Telp : (021) 6506559 ext.5001, email : dianali79@ymail.com

\section{PENDAHULUAN}

Menurut laporan tahunan WHO "Mengontrol Tuberkulosis di Kawasan Asia Tenggara 2012", prevalensi TB sekitar 5 juta dan 3,5 juta kasus baru ditemukan selama 2010. Berdasarkan laporan WHO dalam Global Report 2009, pada tahun 2008 Indonesia berada pada peringkat 5 dunia penderita TB terbanyak setelah India, China, Afrika Selatan dan Nigeria. Peringkat ini turun dibandingkan tahun 2007 yang menempatkan Indonesia pada posisi ke-3 kasus TB terbanyak setelah India dan China ${ }^{1}$.

Pencegahan dapat dilakukan untuk menurunkan angka penularan penyakit TB paru terhadap orang-orang lingkungan sekitar. Perilaku pencegahan penularan TB Paru dengan penerapan pola hidup sehat. Pemahaman masyarakat terhadap TBC sangat kurang, pengetahuan penderita TB Paru yang kurang tentang cara penularan, bahaya dan cara pengobatan akan berpengaruh terhadap perilaku pencegahan penularan pada penderita TB paru padahal pengetahuan tentang pencegahan penularan TB paru merupakan bekal utama untuk mencegah penularan dan penyebaran penyakit Tuberkulosis Paru?

Hasil studi pendahuluan ${ }^{3} \quad 70 \%$ penderita TB tidak mengerti tentang gejala penyakit, 90\% tidak tahu bahwa kuman TB Paru dapat mati jika terkena sinar matahari, $80 \%$ tidak mengetahui bahwa penyakit TB Paru memerlukan 
pengobatan yang lama. Selanjutnya dari perilaku hidup sehat, $70 \%$ responden tidak biasa menutup mulut saat batuk, $70 \%$ tidak biasa membuka ventilasi kamar.

\section{METODOLOGI}

Penelitian ini Penelitian ini merupakan penelitian kuantitatif dengan jenis deskriptif korelatif dengan desain cross sectional yang dilakukan di Poli Paru Paru RS Prof Sulianti Saroso Jakarta Utara pada bulan januari sampai desember 2013. Sampel dalam penelitian ini sebanyak 60 pasien yang diambil dengan teknik random sampling dengan kriteria inklusi semua pasien TB Paru Dewasa usia 18-60 tahun yang memeriksakan kesehatannya dan mendapat pengobatan OAT Intensif di Poli Paru RS Prof Sulianti Sarosos Jakarta Utara, bersedia menjadi responden, bisa membaca dan menulis, kesadaran compos mentis dan kooperatif. Alat Ukur yang digunakan adalah kuesioner yang meliputi instrument pengetahuan sebanyak 18 point dan perilaku sebanyak 9 point. Analisa data meliputi univariat dan bivariat dengan regresi linier sederhana.

\section{HASIL DAN PEMBAHASAN}

\section{Karakteristik Responden}

Tabel 1. Karakteristik Pasien di Poli Paru RS Prof. Dr. Sulianti Saroso Jakarta Utara Tahun 2013

\begin{tabular}{|c|l|l|l|}
\hline \multicolumn{2}{|c|}{ Variabel } & $\mathrm{N}$ & $(\%)$ \\
\hline \multirow{2}{*}{ Usia } & $<30$ tahun & 29 & 48,3 \\
\cline { 2 - 4 } & $\geq 30$ tahun & 31 & 51,7 \\
\hline \multirow{2}{*}{$\begin{array}{c}\text { Jenis } \\
\text { Kelamin }\end{array}$} & Laki-laki & 28 & 46,7 \\
\cline { 2 - 4 } Pendidikan & Perempuan & 32 & 53,3 \\
\hline & $\begin{array}{l}\text { Rendah (< } \\
\text { SMA) }\end{array}$ & 45 & 45,0 \\
\cline { 2 - 4 } & $\begin{array}{l}\text { Tinggi ( } \\
\text { SMA) }\end{array}$ & 55 & 55,0 \\
\hline
\end{tabular}

Berdasarkan karakteristik responden diketahui bahwa sebagian besar responden berusia $\geq 30$ tahun $(51.7 \%$ ). Usia merupakan variabel yang selalu diperhatikan dalam pendidikan penyelidikan epidemiologi. Pada usia sangat muda dan usia tua lebih rentan atau kurang kebal terhadap penyakit tertentu karena kelompok tersebut memiliki daya tahan tubuh yang lebh rendah. Penyakit TBC menjadi masalah sosial, karena sebagian besar penderitanya adalah kelompok usia kerja produktif. Di Indonesia diperkirakan 75\% penderita TB Paru adalah kelompok usia produktif yaitu 15-50 tahun ${ }^{4}$. Hasil penelitian ini sejalan dengan penelitian yang dilakukan di Jakarta Timur pada tahun 2008 yaitu hasil penelitiannya memperoleh bahwa sebagian besar responden berumur lebih dari 20 tahun $75 \%{ }^{5}$.

Hasil penelitian menunjukkan bahwa sebagian besar responden berjenis kelamin perempuan yaitu $32(53,3 \%)$. TB paru lebih banyak terjadi pada laki-laki dibandingkan dengan wanita karena lakilaki sebagian besar mempunyai kebiasaan merokok sehingga memudahkan terjangkitnya TB paru. Kebiasaan merokok meningkatkan resiko untuk terkena TB paru sebanyak 2,2 kali. Prevalensi merokok pada hampir semua Negara berkembang lebih dari $50 \%$ terjadi pada laki-laki dewasa, sedangkan wanita perokok kurang dari $5 \%$. Dengan adanya kebiasaan merokok akan mempermudah untuk terjadinya infeksi TB Paru ${ }^{6}$. Penelitian terkait yang dilakukan kota Salatiga dimana hasil penelitiannya didapat bahwa penderita perempuan lebih banyak dari pada penderita laki-laki, merupakan penderita terbanyak dan penderita terbanyak terdapat di BP4 ${ }^{7}$.

Dari hasil penelitian diketahui bahwa berpendidikan responden sebagian besar yaitu $55(55 \%)$ dalam kategori pendidikan tinggi. Pendidikan seseorang akan mempengaruhi terhadap pengetahuan seseorang diantaranya mengenai rumah yang memenuhi syarat kesehatan dan pengetahuan penyakit TB Paru, sehingga dengan pengetahuan yang cukup maka seseorang akan mencoba untuk mempunyai perilaku hidup bersih dan sehat. Pendidikan menunjukkan kualitas sumber daya manusia yang akan sangat berpengaruh terhadap produktifitas manusia itu sendiri. Dalam pengertian yang sederhana dan umum makna pendidikan sebagai usaha manusia untuk menumbuhkan dan mengembangkan 
potensi-potensi pembawaan baik jasmani maupun rohani sesuai dengan nilai-nilai yang ada didalam masyarakat ${ }^{8,9} \mathrm{Hal}$ tersebut sejalan dengan penelitian terkait yang dilakukan Ponorogo tahun 2006 dimana diperoleh hasil bahwa 62,9\% responden berpendidikan SMA ${ }^{10}$.

\section{Pengetahuan}

Tabel 2. Pengetahuan Pasien di Poli Paru RS Prof. Dr. Sulianti Saroso Jakarta Utara Tahun 2013

\begin{tabular}{|l|l|l|}
\hline Pengetahuan & $\mathrm{N}$ & $\%$ \\
\hline Rendah (nilai 0-42) & 58 & 96,7 \\
\hline Tinggi (43-71) & 2 & 3,3 \\
\hline Jumlah & 60 & 100 \\
\hline
\end{tabular}

Berdasarkan table diatas sebagian besar responden berpengetahuan rendah (nilai 0-24) yaitu sebanyak 58 (96.7\%). Notoadmojo menyimpulkan pengetahuan seseorang mempengaruhi perilaku individu. Semakin tinggi pengetahuan seseorang tentang kesehatan maka akan semakin tinggi kesehatan. Pernyataan ini diperkuat dengan pendapat Ida Bagus Mantra yang mengemukakan bahwa pengetahuan merupakan tahap awal bagi seseorang yang berbuat sesuatu seperti keyakinan atau kepercayaan, saran, dan dorongan/ motivasi ${ }^{8,11}$. Berbeda halnya dengan penelitian yang dilakukan $\mathrm{d}$ Jakarta Timur tahun 2009 dimana terdapat responden yang mempunyai tingkat pengetahuan tinggi sebanyak 72 responden $(60,0 \%)$ maka terdapat perbedaan yaitu sebagian besar responden mempunyai pengetahuan tinggi lebih banyak dari pada pengetahuan rendah ${ }^{12}$.

\section{Perilaku}

Tabel 3. Perilaku Pasien Tentang

Pencegahan Penularan di Poli Paru RS Prof.

Dr. Sulianti Saroso Jakarta Utara Tahun 2013

\begin{tabular}{|l|l|l|}
\hline Perilaku & $\mathrm{N}$ & $\%$ \\
\hline Tidak Mendukung (0-18) & 60 & 100 \\
\hline Mendukung (19-32) & 0 & 0 \\
\hline Jumlah & 60 & 100 \\
\hline
\end{tabular}

Berdasarkan table diatas seluruh responden (0-18) yaitu sebanyak 60 $(100 \%)$ berperilaku tidak mendukung. Perilaku dapat terdiri dari pengetahuan dan tindakan, pengetahuan penderita TB Paru yang kurang tentang cara penularan, bahaya dan cara pengobatan akan berpengaruh terhadap perilaku sebagai orang sakit dan akhirnya berakibat menjadi sumber penularan bagi orang disekelilingnya ${ }^{8}$.

4. Hubungan Pengetahuan Dengan Perilaku Pencegahan

Tabel 4. Hubungan Pengetahuan Dengan Perilaku Pasien Tentang Pencegahan Penularan di Poli Paru RS Prof. Dr. Sulianti Saroso Jakarta Utara Tahun 2013

\begin{tabular}{|c|c|c|c|c|}
\hline Variabel & $\mathrm{R}^{2}$ & Persamaan garis & $\mathrm{P}$ Value & VIT \\
\hline Pengetahuan & 0.116 & $\mathrm{H}=10.521+.092^{*}$ pengetahuan & 0.008 & 1.000 \\
\hline
\end{tabular}

Berdasarkan matrik interkorelasi terlihat bahwa ada hubungan antara pengetahuan dengan perilaku pencegahan penularan TB bermakna dengan uji statistik diperoleh $P$ Value 0.008 berarti $p<0,05$. artinya ada hubungan linier antara pengetahuan dengan perilaku pencegahan penularan TB pada pasien TB. Jadi dapat disimpulkan dengan tingkat kepercayaan $95 \%$, didapat nilai konstanta sebesar 10.52. Responden yang mempunyai perilaku tidak mendukung akan bertambah 0,092 kali bila pengetahuan rendah bertambah setiap tahun dibandingkan dengan responden yang mempunyai pengetahuan tinggi. Hal tersebut sejalan dengan penelitian terkait yang dilakukan di Jakarta Timur tahun 2009 dengan jumlah sampel 120 orang. Hasil penelitian $p$ value 0,012 OR 2,8 menunjukkan dari analisa bivariat ternyata ada hubungan yang bermakna antara pengetahuan mengenai TB Paru dengan perilaku pencegahan TB Paru dengan presentase pengetahuan tinggi mengenai pengertian, penyebab, tanda gejala, pencegahan penularan TB Paru sebanyak $(60 \%)$. Dan presentase perilaku pencegahan TB Paru tertinggi adalah responden yang mempunyai perilaku mencegah penularan TB Paru sebanyak 
$(52,5 \%)$. Perilaku melalui suatu proses tertentu, dan berlangsung dalam interaksi manusia dengan lingkungannya. Begitu pula dengan perilaku pasien TB Paru dalam upaya pencegahan penularan penyakit TB paru. Jadi sebelum terbentuk perilaku (upaya pencegahan penularan) ada beberapa hal yang melatar belakangi seperti pengetahuan/informasi yang diperoleh dan pemahaman atas informasi yang didapat tersebut sebelum ia melakukan tindakan konkrit berupa perbuatan pencegahan penularan penyakit TB paru ${ }^{8,11}$. Dari uraian diatas dapat diketahui bahwa pengetahuan yang dimiliki sangat berpengaruh terhadap cerminan perilaku seseorang, namun pembentukkan perilaku itu sendiri tidak terjadi, semata-mata berdasarkan pengetahuan-pengetahuan, tetapi masih dipengaruhi oleh banyak faktor yang sangat kompleks ${ }^{8}$.

KESIMPULAN
Ada hubungan linier $\begin{array}{r}\text { antara } \\ \text { pengetahuan dengan }\end{array}$ perilaku
pencegahan penularan pada pasien TB.

\section{SARAN}

Saran yang dapat diberikan adalah :

1. Tenaga kesehatan terutama perawat dan dokter harus menjelaskan tentang TB, cara penularan dan pencegahan TB

2. Tambahkan tindakan konseling TB, kemudian lakukan evaluasi pada penderita TB terhadap pengetahuan, sikap dan perilaku pencegahan penularan.

3. Buatkan rencana penyuluhan sesuai pengetahuan pasien, sehingga pasien TB akan mempunyai perilaku yang mendukung pencegahan penularan TB dengan melakukan minum obat secara teratur, menutup mulut dan hidung saat batuk, membuang ludah pada tempatnya dan membuka ventilasi rumah saat pagi hari.

\section{DAFTAR PUSTAKA}

1. World Health Organization. World Health Statistic 2011, Geneva,2011

2. Departemen Kesehatan Republik
Indonesia. Pedoman Nasional Penanggulangan Tuberkulosis. Jakarta : Depkes RI, 2005

3. Suthari, L, B, Hubungan Antara Tingkat Pengetahuan Dengan Perilaku Pencegahan Penularan TB Di Poli Paru Rumah Sakit Pasar Rebu Jakarta Timur, Skripsi, Fakultas IImu Kesehatan Universitas Pembangunan Nasional "Veteran" Jakarta, 2008

4. Departemen Kesehatan Republik Indonesia. Pedoman Nasional Penanggulangan Tuberkulosis. Jakarta : Depkes RI, 2002

5. Perdana, P. Faktor-faktor yang berhubungan dengan kepatuhan berobat penderita TB Paru selama pengobatan di puskesmas kecamatan Ciracas Jakarta Timur, Skripsi, Fakultas IImu Kesehatan Universitas Pembangunan Nasional "Veteran" Jakarta, 2008.

6. Achmadi, U. F, Manajemen Penyakit Berbasis Wilayah, Kompas, Jakarta,2005.

7. Diansyah, A, Insidensi dan tingkat kesembuhan penderita TB Paru dewasa BTA (Basil Tahan Asam) positif dikota salatiga tahun 2003, Fakultas Kedokteran Universitas Islam Indeonesia, Yogyakarta, 2003.

8. Notoatmodjo,S,Promosi Kesehatan dan IImu Perilaku, PT Rhineka Cipta, Jakarta, 2007

9. Ihsan Fuad. Dasar-dasar Kependidikan, PT Rhineka Cipta, Jakarta, 2005

10. Wahyudi, E. Hubungan antara pengetahuan tentang penyakit TB Paru dengan tindakan pencegahan penularan pada keluarga penderita TB Paru di wilayah kerja Puskesmas Ponorogo Utara Kecamatan Ponorogo kabupaten ponorogo. Unair, Surabaya, 2006.

11. Mantra, Ida Bagus. Demografi Umum. Yogyakarta : Pustaka Pelajar, 2003.

12. Kusmiati, Dasar-dasar perilaku, Jakarta : Penerbit Depkes RI, 1990. 